\section{Assessment of proliferating cell nuclear antigen and its relationship with proinflammatory cytokines and parameters of disease activity in multiple myeloma patients}

\author{
G. Tsirakis, ${ }^{1}$ C.A. Pappa, ${ }^{2}$ M. Kaparou, ${ }^{1}$ \\ V. Katsomitrou, ${ }^{1}$ A. Hatzivasili, ${ }^{2}$ \\ T. Alegakis, ${ }^{3}$ A. Xekalou, ${ }^{4}$ \\ E.N. Stathopoulos, ${ }^{4}$ M.G. Alexandrakis ${ }^{1}$ \\ 'Department of Haematology, University \\ Hospital of Heraklion; \\ 2Department of Haematology, Venizelion \\ Hospital of Heraklion; \\ ${ }^{3}$ Department of Social Medicine, School \\ of Medicine, University of Crete, \\ ${ }^{4}$ Department of Pathology, University \\ Hospital of Heraklion, Crete, Greece
}

\section{Abstract}

Multiple myeloma (MM) is a malignant plasma cell disease. Several proinflammatory cytokines produced by malignant plasma cells and bone marrow (BM) stromal cells are involved in the pathogenesis of the disease. We evaluated serum levels of the proinflammatory cytokines Interleukin-1 $\beta$ (IL-1 $\beta$ ), Interleukin-6 (IL-6), Interleukin-8 (IL-8), macrophage inflammatory protein-1 $\alpha$ (MIP-1 $\alpha)$, in MM patients before treatment, and determined its significance in tumor progression. We also analyzed the correlation between measured parameters with proliferating cell nuclear antigen (PCNA). Forty-four MM patients and 20 healthy controls were studied. Serum levels of the proinflammatory cytokines were measured using enzymelinked immunosorbent assay (ELISA), whereas PCNA value in the BM was determined by immunohistochemistry staining. The mean concentrations of the measured cytokines were significantly different among the three stages of disease, with higher values in advanced disease stage. Furthermore, patients with MM had significantly higher serum levels of the measured cytokines than in controls. A positive correlation was found between IL- 6 with IL-1 $\beta$, IL- 8 and MIP-1 $\alpha$. Similarly, IL- 8 and MIP-1 $\alpha$ were positively correlated with markers of disease activity such as $\beta 2$ microglobulin and LDH. The proliferation index, determined by PCNA immunostaining, was higher in advanced disease stage. Furthermore PCNA value correlated significantly with $\beta 2$ microglobulin, LDH and the levels of the measured cytokines. Our results showed that the proliferative activity, as measured with PCNA, increases in parallel with disease stage. The positive correlation between PCNA and other measured mediators supports the involvement of these factors in the biology of myeloma cell growth and can be used as markers of disease activity and as possible therapeutic targets.

\section{Introduction}

Multiple myeloma (MM) is characterized by the slow proliferation of malignant plasma cells. Various cytokines control growth, progression and dissemination of the disease. ${ }^{1}$ Interleukin 6 (IL-6) has been recognized as the major human myeloma cell growth factor in vitro and induces the differentiation of B-cells to plasma cells, which produce monoclonal antibodies and acutephase proteins. ${ }^{2}$ Several nuclear proteins have been described as proliferative markers in normal, neoplastic and transformed cells. ${ }^{3}$ Plasma cell nuclear antigen (PCNA) well correlates with cellular proliferation in benign and malignant neoplasms, including haematological malignancies;, 45 its level of expression varies during the cell cycle, suggesting that under certain conditions PCNA is a marker of S-phase cells. ${ }^{6}$

The role of interleukin $1 \beta$ (IL-1 $\beta$ ) in the pathogenesis of MM remains controversial. Several studies found elevated levels of IL-1 $\beta$ in MM patients, suggesting that MM cells produce IL- $1 \beta .{ }^{7}$ IL- $1 \beta$ is a potent inducer of IL- 6 production in stromal cells and monocytes ${ }^{8}$ and has an important role of IL-1 $\beta$ in myeloma bone disease. ${ }^{9}$ Interleukin 8 (IL-8) is a chemokine that targets neutrophils and lymphocytes. Stromal cells, co-cultured with supernatants from bone marrow cells of patients with active myeloma, produce elevated amounts of IL- $8 .{ }^{10}$ IL-8 plays a significant role in inflammatory and tumor associated angiogenesis and tumor progression. ${ }^{11}$

Macrophage inflammatory protein-1 $\alpha$ (MIP$1 \alpha$ ) is a chemokine that stimulates phagocyte activity, ${ }^{12}$ and belongs to the RANTES family of chemokines, which act as chemoattractant and activators of monocytes. ${ }^{13}$ MIP- $1 \alpha$ interaction with CCR2 receptors activates secretion of numerous proinflammatory signals. ${ }^{14}$ Furthermore, MIP-1 $\alpha$ secreted from bone marrow cells of MM patients stimulates bone absorption. ${ }^{15,16}$ The aims of the present study were to measure circulating levels of proinflammatory cytokines, such as IL-1 $\beta$, IL-6, IL-8, MIP- $1 \alpha$, as well as LDH and $\beta 2$ microglobulin, which were identified as strong and independent prognostic factors in multiple myeloma ${ }^{17-19}$ and to discuss its significance in tumor progression. Additionally, we analyzed the correlation of measured mediators with the proliferative activity assessed by PCNA immunohistochemistry staining.
Correspondence: Michael G. Alexandrakis, Department of Haematology, University Hospital of Heraklion, P.0. Box 1352, Heraklion, Crete, Greece.

Tel. +30.2.810392425 - Fax: +30.2 .810244883 .

E-mail: alexandm@med.uoc.gr

Key words: Multiple myeloma, Interleukin-6, Interleukin-8, Interleukin-1 $\beta$, MIP-1 $\alpha$, proliferating cell nuclear antigen.

Aknowledgement: the authors would like to thank Mrss. Maria Klinaki and Georgia Fiolitaki for their excellent technical assistance, and Mrs Anjali Verghese for the correction of the manuscript.

Contributions: GT, VK, AX, ENS, performed the experiments; CAP, MK, AH, MGA, experiments design, manuscript writing; TA, reformed statistical analysis.

Received for publication: 18 March 2011 Accepted for publication: 21 April 2011.

This work is licensed under a Creative Commons Attribution NonCommercial 3.0 License (CC BYNC 3.0).

(C) Copyright G. Tsirakis et al., 2011

Licensee PAGEPress, Italy

European Journal of Histochemistry 2011; 55:e21 doi:10.4081/ejh.2011.e21

\section{Materials and Methods}

\section{Patients}

Forty-four patients with MM (24 male and 20 female, mean age $66 \pm 10.2$ years) were enrolled in the study. Blood samples were obtained from all patients at diagnosis and none of them had recent apparent infections or had received treatment with cytostatic drugs in the past. The frequencies of M-protein isotypes were $61.8 \%$ IgG, 29.4\% IgA and 8.8\% light chain only. According to the criteria of Durie and Salmon's myeloma staging system, ${ }^{20}$ at the time of serum collection, 12 patients had stage I, 14 had stage II and 18 had stage III. Biopsies were taken from the posterior iliac crests using a manual trephine. Twenty age-matched healthy volunteers ( 8 female and 12 male, mean age $64.4 \pm 12.1$ years) were used as controls.

\section{Methods}

All blood samples were taken after informed consent was given and were stored at $-70^{\circ} \mathrm{C}$. Solid-phase sandwich enzyme-linked immunosorbent assay (ELISA) with monoclonal human antilL-6, antilL-1 $\beta$, antilL-8, and antiMIP- $1 \alpha$ antibodies from commercially available kits (Quantikine $^{\circledR}$, R\&D Systems, Inc., Minneapolis, MN, USA) was used to measure 
the above cytokines. An immunostaining method was used to detect PCNA. The biopsies were fixed in $10 \%$ neutral formalin for at least $24 \mathrm{~h}$, and decalcified in 10\% EDTA for $48 \mathrm{~h}$, and then embedded in Paramat extra (BDH Laboratory Supplies, Pool, UK). Initially, Hematoxylin-Eosin (H\&E) stained $3 \mu$ m-thick section from each Paramat-embedded bone marrow biopsy was double-immunostained with antibodies to PCNA (M 0879, DK-2600, Dako, Glostrup, Denmark) and CD38 (M 7077, DK-2600, Dako), using the DAK0 Envision system (En Vision HRP-conjugated polymer, Kit 5007, Dako). ${ }^{21}$

\section{Statistical analysis}

Mean values were expressed as mean \pm SD. Statistical analysis was performed using one analysis of variance (ANOVA) to test the existence of differences between different stages. A post-hoc multiple comparisons test, StudentNewman-Keuls (SNK) was carried out to determine differences between means. Statistical comparison between MM group and control group was made using the nonparametric Mann-Whitney test. Correlations were assessed using the Spearman correlation coefficient. Multiple logistic regressions analysis with forward selection was applied to estimate the risk (in the form of odd's ratios) of having multiple myeloma based on hematological and histological parameters. A P value of $<0.05$ was considered statistically significant.

\section{Results}

The mean concentrations of the measured cytokines in the entire group of patients are shown in Table 1. All the above measured parameters were significantly different among the three stages of disease, with higher values in advancing disease stage (Table 1 and Figure 1). Furthermore, serum levels of IL-6, IL-1 $\beta$, IL8 and MIP- $1 \alpha$ were significantly higher in patients with MM compared to controls. A positive correlation was found between IL- 6 with IL-1 $\beta \quad(r=0.462, \quad \mathrm{P}<0.002), \quad$ IL-8 $\quad(r=0.358$, $\mathrm{P}<0.01)$ and $\mathrm{MIP}-1 \alpha(\mathrm{r}=0.380, \mathrm{P}<0.001)$. Similarly, IL- 8 and MIP-1 $\alpha$ were positively correlated with factors of disease activity such as $\beta 2$ microglobulin ( $\mathrm{r}=0.502, \mathrm{P}<0.001 ; \mathrm{r}=0.413$, $\mathrm{P}<0.005$, respectively) and $\mathrm{LDH}(\mathrm{r}=0.415$, $\mathrm{P}<0.006 ; \mathrm{r}=0.475, \mathrm{P}<0.001$, respectively). The mean PCNA values are shown in Table 1. PCNA expression was higher in advanced disease stage (Table 1 and Figure 2). Furthermore, PCNA expression correlated significantly with parameters of disease activity such as $\beta 2$ microglobulun and LDH $(\mathrm{r}=0.406, \mathrm{P}<0.006$; $\mathrm{r}=0.581, \mathrm{P}<0.0001$, respectively). Similarly, PCNA value correlated with the measured

cytokines IL-6, IL-1 $\beta$ (results not shown graphically), IL-8 (Figure 3) and MIP-1 $\alpha$ (Figure 4) $(\mathrm{r}=0.520, \quad \mathrm{P}<0.0001 ; \quad \mathrm{r}=0.545, \quad \mathrm{P}<0.0001 ;$ $\mathrm{r}=0.320, \mathrm{P}<0.03$ and $\mathrm{r}=0.383, \mathrm{P}<0.01$, respectively).

The multivariate analysis showed that IL-1 $\beta$ and $\beta 2$ microglobulin are independent prognostic factors (7.89 95\% CI: $1.75-35.66$ for IL$1 \beta$ and $7.4795 \% \mathrm{CI}$ : $1.66-33.65$ for $\beta 2$ microglobulin).

\section{Discussion}

The data presented in this study show that serum concentrations of IL-6, IL-8, IL-1 $\beta$ MIP$1 \alpha, \mathrm{LDH}$ and $\beta 2$ microglobulin in patients with MM are significantly higher than normal controls. Furthermore, these parameters are positively correlated with advancing disease stage. We also found a significant correlation

Table 1. Measured parameters (Means \pm SD) for controls and multiple myeloma patients according to disease stage.

\begin{tabular}{lccccc} 
& Controls & MM patients & Stage I & Stage II & Stage III \\
B2M (mg/L) & $1.2 \pm 0.5^{\mathrm{a}}$ & $3.1 \pm 0.7$ & $2.0 \pm 0.6$ & $2.5 \pm 0.8$ & $4.2^{2} \pm 2.0^{\mathrm{b}}$ \\
LDH (U/mL) & $176.2 \pm 27.3^{\mathrm{a}}$ & $284.0 \pm 103.1$ & $200.4 \pm 38.7$ & $258.8 \pm 51.7$ & $349 \pm 113.7^{\mathrm{c}}$ \\
\hline IL-1 $(\mathrm{pg} / \mathrm{mL})$ & $0.7 \pm 0.5^{\mathrm{a}}$ & $2.8 \pm 1.3$ & $1.5 \pm 0.6$ & $2.8 \pm 1.0$ & $3.7 \pm 1.0^{\mathrm{b}}$ \\
PCNA $(\%)$ & $2.0 \pm 1.7^{\mathrm{a}}$ & $26.8 \pm 24.7$ & $6.6 \pm 5.2$ & $24.0 \pm 12.4$ & $41.4 \pm 29.0^{\mathrm{b}}$ \\
\hline IL-8 $(\mathrm{pg} / \mathrm{mL})$ & $27.6 \pm 5.8^{\mathrm{a}}$ & $39.3 \pm 15.6$ & $28.6 \pm 18.1$ & $37.4 \pm 12.2$ & $47.3 \pm 18.1^{\mathrm{b}}$ \\
MIP-1 $(\mathrm{pg} / \mathrm{mL})$ & $22.4 \pm 4.2^{\mathrm{a}}$ & $51.7 \pm 34.9$ & $33.9 \pm 21.7$ & $39.4 \pm 20.5$ & $71.4 \pm 40.2^{\mathrm{d}}$ \\
\hline IL-6 $(\mathrm{pg} / \mathrm{mL})$ & $0.9 \pm 0.4^{\mathrm{a}}$ & $6.2 \pm 5.9$ & $1.8 \pm 0.4$ & $3.6 \pm 1.8$ & $10.9 \pm 6.4^{\mathrm{b}}$ \\
\hline
\end{tabular}

MM, multiple myeloma; ${ }^{\mathrm{M} M M}$ group $v$ s control group, $\mathrm{P}<0.001$ (Mann-Whitney test); ${ }^{b}$ among disease stages, $\mathrm{P}<0.001$; camong disease stages, $\mathrm{P}<0.02$; dbetween stages I and II, $\mathrm{P}=0.896$ and between stages I and III, $\mathrm{P}<0.001$.

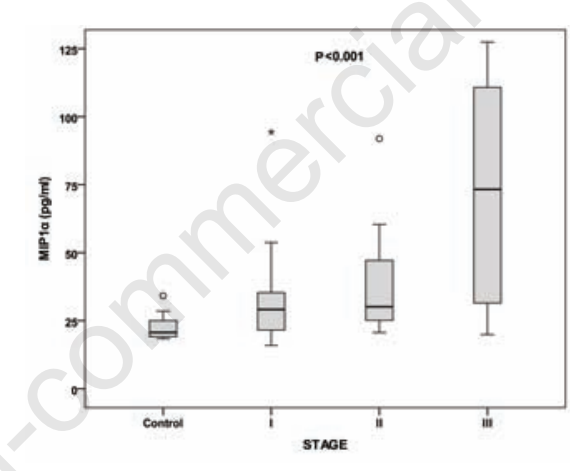

Figure 1. Levels of MIP-1 $\alpha$ in controls and the three stages of multiple myeloma. Among stages $(\mathrm{P}<0.001)$, between controls and multiple myeloma patients $(P<0.001)$.

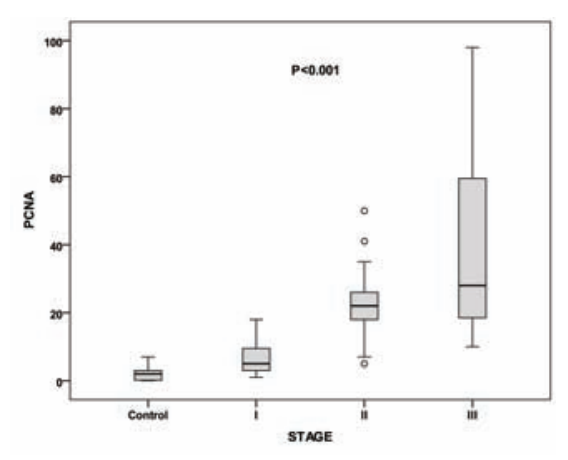

Figure 2. Proliferating cell nuclear antigen values in controls and the three stages of multiple myeloma. Among stages $(P<0.001)$, between controls and multiple myeloma patients $(\mathrm{P}<0.001)$.

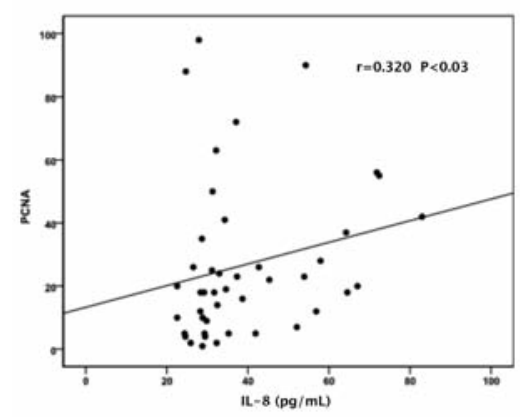

Figure 3. Correlation of proliferating cell nuclear antigen with IL-8.

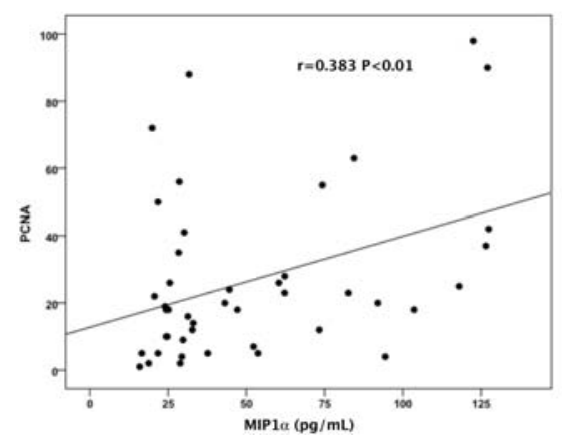

Figure 4. Correlation of proliferating cell nuclear antigen with MIP-1 $\alpha$. 
between serum IL-6 and disease stage, suggesting that IL- 6 is a central growth and survival factor for MM cells. ${ }^{22} \mathrm{IL}-1 \beta$ is a proinflammatory cytokine stimulating IL-6 and IL-8 production in the stromal cells and has been implicated in inflammatory and malignant disorders. ${ }^{8,23}$ Although IL-1 $\beta$ is the major osteoclast stimulating factor in MM, a previous report $^{13}$ failed to confirm the role for this cytokine in the pathogenesis of myeloma bone disease. Our results showed that serum levels of IL-1 $\beta$ were significantly increased with advanced of disease stage and correlated significantly with factors of disease activity, such as LDH and $\beta 2$ microglobulin, in patients with normal renal function. Additionally IL-1 $\beta$ could be an independent prognostic factor as our results showed.

IL-8 plays a significant role in inflammation and tumor associated angiogenesis ${ }^{24,25}$ and has been found to significantly increase microvascular density in several systems. Furthermore, IL-8 is a chemotactic and growth factor in several tumors. ${ }^{26,27}$ We found a significantly higher serum concentration of IL- 8 in MM patients at diagnosis compared to controls. Serum IL-8 was significantly correlated with MM stage and disease activity. It was previously demonstrated that IL-8 stimulates the proliferation and migration of MM cells. ${ }^{28}$

We also found that PCNA value increased with advancing disease stage and correlated significantly with prognostic factors, such as IL-6, $\beta 2$ microglobulin and LDH. Another interesting observation of our study was the strong correlation between PCNA and serum levels of MIP-1 $\alpha$, an important mediator of the bone destruction in patients with MM. The correlation of MIP-1 $\alpha$ with advanced disease stage and the other measured cytokines, suggests that there is an important role of MIP- $1 \alpha$ in the biology of myeloma, which can be explained by its impact on plasma cell proliferation and growth. ${ }^{18}$

In conclusion, our results showed that the proliferative activity increases with disease stage. The positive correlation between PCNA and other measured mediators supports the involvement of these factors in the biology of myeloma cell growth and can be used as markers of disease activity and as possible therapeutic targets.

\section{References}

1. Lauta VM. A review of the cytokine network in multiple myeloma: diagnostic, prognostic, and therapeutic implications. Cancer 2003;97:2440-52.

2. Hirano T. Interleukin 6 and its receptor: ten years later. Int Rev Immunol 1998;

\section{6:249-84.}

3. Skopelitou A, Tselenis S, Theocharis S, Agnantis N, Tsenga A, Elemenoglou J, et al. Expression of proliferating cell nuclear antigen (PCNA) and nucleolar organizer regions (NORs) in multiple myeloma. Anticancer Res 1994;14:787-92.

4. Alexandrakis MG, Passam FH, Pappa CA, Dambaki C, Sfakiotaki G, Alegakis AK, et al. Expression of proliferating cell nuclear antigen (PCNA) in multiple myeloma: its relationship to bone marrow microvessel density and other factors of disease activity. Int J Immunopathol Pharmacol 2004;17: 49-56.

5. Wilkins BS, Harris S, Waseem NH, Lane DP, Jones DB. A study of cell proliferation in formalin-fixed, wax-embedded bone marrow trephine biopsies using the monoclonal antibody PC10, reactive with proliferating cell nuclear antigen (PCNA). J Pathol 1992;166:45-52.

6. Zölzer F, Basu 0, Devi PU, Mohanty SP, Streffer C. Chromatin-bound PCNA as Sphase marker in mononuclear blood cells of patients with acute lymphoblastic leukaemia or multiple myeloma. Cell Prolif 2010;43:579-83.

7. Lacy MQ, Donovan KA, Heimbach JK, Ahmann GJ, Lust JA. Comparison of interleukin-1 beta expression by in situ hybridization in monoclonal gammopathy of undetermined significance and multiple myeloma. Blood 1999;93:300-5.

8. Dinarello CA. Biologic basis for interleukin-1 in disease. Blood 1996;87:2095147.

9. Dinarello CA. Blocking interleukin-1 $\beta$ in acute and chronic autoinflammatory diseases. J Intern Med 2011;269:16-28.

10. Kline M, Donovan K, Wellik L, Lust C, Jin W, Moon-Tasson L, et al. Cytokine and chemokine profiles in multiple myeloma; significance of stromal interaction and correlation of IL- 8 production with disease progression. Leuk Res 2007;31:591-8.

11. Strieter RM, Polverini PJ, Arenberg DA, Walz A, Opdenakker G, Van Damme J, et al. Role of C-X-C chemokines as regulators of angiogenesis in lung cancer. J Leukoc Biol 1995;57:752-62.

12. Cook DN. The role of MIP-1 alpha in inflammation and hematopoiesis. J Leukoc Biol 1996;59:61-6.

13. Choi SJ, Cruz JC, Craig F, Chung H, Devlin RD, Roodman GD, et al. Macrophage inflammatory protein 1-alpha is a potential osteoclast stimulatory factor in multiple myeloma. Blood 2000;96:671-5.

14. Vande Broek I, Asosingh K, Vanderkerken K, Straetmans N, Van Camp B, Van Riet I. Chemokine receptor CCR2 is expressed by human multiple myeloma cells and mediates migration to bone marrow stromal cell-produced monocyte chemotactic proteins MCP-1, -2 and -3 . Br J Cancer 2003;88:855-62.

15. Uneda S, Hata H, Matsuno F, Harada N, Mitsuya Y, Kawano F, et al. Macrophage inflammatory protein-1 alpha is produced by human multiple myeloma (MM) cells and its expression correlates with bone lesions in patients with $\mathrm{MM}$. $\mathrm{Br} \mathrm{J}$ Haematol 2003;120:53-5.

16. Cao Y, Luetkens T, Kobold S, Hildebrandt Y, Gordic M, Lajmi N, et al. The cytokine/chemokine pattern in the bone marrow environment of multiple myeloma patients. Exp Hematol 2010;38:860-7.

17. Suguro M, Kanda Y, Yamamoto R, Chizuka A, Hamaki T, Matsuyama T, et al. High serum lactate dehydrogenase level predicts short survival after vincristine-doxorubicin-dexamethasone (VAD) salvage for refractory multiple myeloma. Am J Hematol 2000;65:132-5.

18. Terpos E, Katodritou E, Roussou M, Pouli A, Michalis E, Delimpasi S, et al. High serum lactate dehydrogenase adds prognostic value to the international myeloma staging system even in the era of novel agents. Eur J Haematol 2010;85:114-9.

19. Alexandrakis MG, Passam FH, Boula A, Christophoridou A, Aloizos G, Roussou P, et al. Relationship between circulating serum soluble interleukin- 6 receptor and the angiogenic cytokines basic fibroblast growth factor and vascular endothelial growth factor in multiple myeloma. Ann Hematol 2003;82:19-23.

20. Durie BG, Salmon SE. A clinical staging system for multiple myeloma. Correlation of measured myeloma cell mass with presenting clinical features, response to treatment, and survival. Cancer 1975;36: 842-54.

21. Pappa C, Miyakis S, Tsirakis G, Sfiridaki A, Alegakis A, Kafousi M, Stathopoulos EN, Alexandrakis MG. Serum levels of interleukin-15 and interleukin-10 and their correlation with proliferating cell nuclear antigen in multiple myeloma. Cytokine 2007;37:171-5.

22. Xiong Y, Donovan KA, Kline MP, Gornet MK, Moon-Tasson LL, Lacy MQ, et al. Identification of two groups of smoldering multiple myeloma patients who are either high or low producers of interleukin-1. J Interferon Cytokine Res 2006;26:83-95.

23. Donovan KA, Lacy MQ, Gertz MA, Lust JA. IL-1beta expression in IgM monoclonal gammopathy and its relationship to multiple myeloma. Leukemia 2002;16:382-5.

24. Baggiolini M. Chemokines in pathology and medicine. J Intern Med 2001;250:91-104.

25. Xie K. Interleukin-8 and human cancer biology. Cytokine Growth Factor Rev 2001; 12:375-91. 
26. Li A, Dubey S, Varney ML, Dave BJ, Singh RK. IL-8 directly enhanced endothelial cell survival, proliferation, and matrix metalloproteinases production and regulated angiogenesis. J Immunol 2003;170:336976 .
27. Romagnani P, Lasagni L, Annunziato F, Serio M, Romagnani S. CXC chemokines: the regulatory link between inflammation and angiogenesis. Trends Immunol 2004;25:201-9.

28. Pellegrino A, Ria R, Di Pietro G, Cirulli T,
Surico G, Pennisi A, et al. Bone marrow endothelial cells in multiple myeloma secrete CXC-chemokines that mediate interactions with plasma cells. $\mathrm{Br} \mathrm{J}$ Haematol 2005;129:248-56. 